\title{
Ergonomic intervention in Aonla pricking operation during preserve preparation in food processing industries
}

\author{
Arpana Rai ${ }^{\mathrm{a}, 1}$, Sudesh Gandhi ${ }^{\mathrm{b}}$, Nitin Kumar ${ }^{\mathrm{c}}$, D.K.Sharma ${ }^{\mathrm{d}}$ and M.K.Garg ${ }^{\mathrm{e}}$ \\ ${ }^{a}$ Deptt. of Family Resource Management, COHS, CCSHAU, Hisar, Haryana, India \\ ${ }^{b}$ Deptt. of Family Resource Management, COHS, CCSHAU, Hisar ,Haryana, India \\ ${ }^{c}$ Deptt of AP\&FE, COA\&E,CCSHAU, Hisar, Haryana, India. \\ ${ }^{d}$ Deptt. Of AP\&FE, COA\&E, CCSHAU, Hisar, Haryana, India. \\ ${ }^{e}$ Dean, COA\&E, CCSHAU, Hisar, Haryana, India.
}

\begin{abstract}
Aonla is an important Indian fruit crop with great potential for processing into various quality products. Aonla preserve making is an important economic activity in our country. The pricking methods are age old, hence a hand operated aonla pricking machine was introduced in preserve making industries to speed up the pricking task. OWAS and RULA two of the most commonly used ergonomic assessment tools were evaluated for their efficacy in the assessment pricking along with Rating of perceived exertion scale. Analysis of working posture using RULA revealed that the pricking task with existing methods i.e. fork and hand tool requires immediate investigation and changes in working posture while with machine pricking investigations and changes are required soon. The results of OWAS indicated that the posture maintained while pricking with existing methods need to be changed in future planning while with machine was acceptable. The subjective assessment revealed that machine pricking was less exerting activity as compared to the existing methods. The preserve prepared from machine pricked fruit was most acceptable among consumers. Hence, in the form of machine ergonomic intervention was brought about in preservation industries which have proved beneficial for workers in terms of their safety and productivity.
\end{abstract}

Keywords: ergonomic assessment tools, aonla pricking machine, preserve.

\section{Introduction}

India has entered into an era of surplus production of fruits and vegetables. But most of them need to be processed to make them fit for consumption and to improve their nutritional value and shelf life. This all has resulted into rapid growth of food processing industries in our country. Besides this huge food production and large number of processing industries, the processing of fruits and vegetables is estimated to be around $2.2 \%$ of the total production in the country. This is because a huge number of entrepreneurs in food processing industries, especially in fruit and vegetable processing segment, are small in terms of their production and operations, and are largely concentrated in the unorganized segment. Unfortunately due to lack of proper machinery and infrastructure the amount cultivated is not processed efficiently into quality products resulting into a huge wastage of the produce.

Preserve preparation is a major economic activity in India especially aonla preserve is very famous among Indians. Aonla (Emblica officinalis) is an important Indian fruit crop. The nutritional quality, ease of long distance transportation and vitamin $\mathrm{C}$ stability are properties of fruit that makes it interest of commercial exploitation. A number of processed products like preserve, RTS, squash, are prepared from aonla fruit to improve their acceptability and exploit nutritional qualities, besides its use in ayurvedic formulations [4].

${ }^{1}$ Corresponding author

Email:arpanahau@gmail.com 
The preserve making starts with pricking individual fruit by hand employing age old tools like fork and hand tools, making the task tiresome, time consuming and hazardous for workers. Further they work in awkward posture which may lead to musculoskeletal problems among them. Researchers are paying due attention towards processing aspects of aonla fruits and this requires an urgent need to design matching processing equipment such as pricking machine.

Despite labor intensive work in food processing units, the awareness of ergonomics in this sector is quite poor at present. So this study is a small attempt to bring about Ergonomic intervention in Aonla pricking methods during preserve preparation in food processing industries by evaluating the existing methods and introducing new technology in form of pricking machine developed by the All India coordinated Research Project on Post Harvest Technology, Hisar in College of Agricultural Engineering and Technology with the ultimate aim of enhancing the overall quality of work [1].

\section{Material and methods}

6 female workers were selected from preserve making industries of Hisar Distt, Haryana for pricking with three methods viz. Fork, hand tool, aonla pricking machine respectively for $20 \mathrm{~min}$ each. All the subjects were in sound health and were interested to contribute in research activities. OWAS and RULA two of the most commonly used Ergonomic Assessment Tools (EATs) along with Rating of perceived exertion were evaluated for their efficacy in the assessment pricking. This study aimed to address: Are different tasks subjectively perceived, using Ratings of perceived exertion/discomfort (RPE/RPD), as having different levels of discomfort and exertion?; Are different tasks objectively rated, using EAT outcome measures, as having different risks of developing work related musculoskeletal disorders (WMSDs)?; Is the rank order of tasks using EATs outcome measures the same as the rank using RPE/RPD scales? Psychophysical, Inertial Measurement Unit (IMU) and video data were collected. RPE/RPD and EAT outcome measure scores were calculated for a shortlist of tasks performed by the majority of the participants.

\subsection{Objective evaluation of Subjects}

\subsubsection{OWAS method}

OWAS (Ovako Working Posture Analysis) is a simple observational method for postural analysis. A video during pricking action, showing different movements of worker was recorded and then was cropped after every 10 seconds to get snapshots for analysis of posture. The snapshots were analyzed to fill the score of OWAS sheet. The OWAS method uses the concept of number to represent posture with an associated coding system. The jobs with the involvement of high risk were numbered higher and those with the less risk involvement were numbered low and thereafter immediate corrective actions and necessary changes were recommended [5].

\subsubsection{RULA method}

RULA (Rapid Upper Limb Assessment) is a survey method developed for ergonomics investigations of workplaces where work related upper limb disorders are reported. It uses the diagram of body posture including movement of arms, wrist, neck, trunk and legs by scoring method including three scoring table to evaluate the level of exposure of risk factors. A coding system is used to generate an action list which indicates the level of interventions required to reduce the risk of injury due to physical loading on the operator [2].

\subsection{Subjective Evaluation of Subjects}

\subsubsection{Rating of perceived exertion}

Subjective perception of exertion of the subjects of the subjects known as Rating of perceived exertion (RPE) was determined on a 5 point continuum ranging from very light exertion(1) to heavy exertion(5) [6].

\subsection{Quality of preserve}

Sensory analysis using Hedonic rating scale was carried out to judge the quality of aonla preserve prepared by using all three methods of pricking [3]. 


\section{Results and discussions}

The results of the study revealed following findings-

\subsection{RULA results}

Findings of RULA revealed that the first two existing methods i.e. fork and hand tool were falling in the RULA action category 4 indicating that current pricking postures were not acceptable and investigation and changes are required immediately and with machine were falling in the action category 3 indicating that investigation and changes are required soon. This is because with fork and hand tool the pricking work involves high back and forth movement of wrist joint, upper and lower arm and inward rotation and continuous stress on palm and fingers. The task also requires greater bending of neck and trunk and that too for long time. However the involvement of muscles and force was low. While with machine, the range of movement of upper arm, lower arm, wrist and wrist twist were same as those with fork and hand tool, however, the bending of neck and trunk was very low and the workers were standing with body weight evenly distributed over both feet. The workers adopted awkward posture and all suffered from musculoskeletal problems mainly in wrist, upper and lower arm, neck and trunk. However the problems were more severe with existing methods than with machine. To overcome such problems, the postures need to be corrected as soon as possible. This modification will increase safety of the workers.

Table 1

Scoring of posture while pricking with fork, hand tool and machine

\begin{tabular}{llllll}
\hline Body part & Fork & \multicolumn{3}{l}{ Hand tool } & Machine \\
\hline Group A & RH & LH & RH & LH & RH \\
\hline Upper arm & 3 & 3 & 3 & 3 & 2 \\
\hline Lower arm & 1 & 2 & 1 & 2 & 1 \\
\hline Wrist & 2 & 1 & 2 & 1 & 2 \\
\hline Wrist-twist & 1 & 2 & 1 & 2 & 1 \\
\hline Total posture score A & $\mathbf{4}$ & $\mathbf{4}$ & $\mathbf{4}$ & $\mathbf{4}$ & $\mathbf{3}$ \\
\hline Force & 2 & 2 & 2 & 2 & 2 \\
\hline Muscle use & 1 & 1 & 1 & 1 & 1 \\
\hline Total score C $=$ & $\mathbf{7}$ & $\mathbf{7}$ & $\mathbf{7}$ & $\mathbf{7}$ & $\mathbf{6}$ \\
ScoreA+force+muscleuse & & & & & \\
\hline Group B & & & & & \\
\hline Neck & 3 & & 3 & & 1 \\
\hline Trunk & 3 & & 3 & & 2 \\
\hline Legs & 1 & & & 1 \\
\hline Total posture score B & $\mathbf{4}$ & $\mathbf{4}$ & $\mathbf{2}$ \\
\hline Force & 2 & & 2 & 2 \\
\hline Muscle use & 1 & & 1 & 1 \\
\hline
\end{tabular}

\begin{tabular}{llll}
\hline $\begin{array}{l}\text { Total score } \mathbf{D}= \\
\text { ScoreB+force+muscleuse }\end{array}$ & 7 & 7 & 5 \\
\hline Total Grand Score & 7 & 7 & 6 \\
\hline
\end{tabular}

Table 2

Interpretation of Results of RULA

\begin{tabular}{clcc}
\hline $\begin{array}{l}\text { Action } \\
\text { level }\end{array}$ & $\begin{array}{l}\text { RULA } \\
\text { Score }\end{array}$ & Risk level & $\begin{array}{l}\text { Pricking } \\
\text { method }\end{array}$ \\
\hline 1 & 1 or 2 & acceptable & -
\end{tabular}

\begin{tabular}{ccll}
\hline 2 & 3 or 4 & Investigate further & - \\
\hline 3 & 5 or 6 & $\begin{array}{l}\text { Investigate further and } \\
\text { change soon }\end{array}$ & Machine \\
\hline 4 & 7 & $\begin{array}{l}\text { Investigate and change } \\
\text { immediately }\end{array}$ & $\begin{array}{l}\text { Fork and } \\
\text { hand tool }\end{array}$ \\
\hline
\end{tabular}

\subsection{OWAS results}

The results of OWAS indicated that the working with fork and hand tool involved bent back, both arms below shoulder level, legs in sitting posture, working with load less than $10 \mathrm{~kg}$, categorizing the whole posture into action category 2 indicating that work postures have some harmful effect on musculoskeletal system and change should be considered in future planning. Whereas with machine the workers were working with back straight, both arms below shoulder level, standing on both legs and working with a load less than $10 \mathrm{~kg}$ categorizing the whole posture into action category 1 indicating that work postures have no particular harmful effect on musculoskeletal system. The awkward posture with fork and hand tool leads to musculoskeletal problems related to back, neck which are very common among working population.

Table 3

The OWAS method for back, arms and legs posture

\begin{tabular}{llll}
\hline Posture & Fork & $\begin{array}{l}\text { Hand } \\
\text { tool }\end{array}$ & Machine \\
\hline Back & & & \\
\hline Straight & - & - & 1 \\
\hline Bent & 2 & 2 & - \\
\hline Twisted & - & - & - \\
\hline Bent and twisted & - & - & - \\
\hline Arms & & & 1 \\
\hline $\begin{array}{l}\text { Both below } \\
\text { shoulder level }\end{array}$ & 1 & 1 & - \\
\hline $\begin{array}{l}\text { One above } \\
\text { shoulder level }\end{array}$ & - & - & - \\
\hline $\begin{array}{l}\text { Both above } \\
\text { shoulder level }\end{array}$ & - & - & \\
\hline
\end{tabular}




\begin{tabular}{llll}
\hline legs & & & \\
\hline sitting & 1 & 1 & - \\
\hline $\begin{array}{l}\text { Standing on two } \\
\text { legs }\end{array}$ & - & - & - \\
\hline $\begin{array}{l}\text { Standing on one } \\
\text { leg }\end{array}$ & - & - & - \\
\hline $\begin{array}{l}\text { Sitting on two } \\
\text { bent knees }\end{array}$ & - & - & \\
\hline $\begin{array}{l}\text { Sitting on one } \\
\text { bent knees }\end{array}$ & - & - & - \\
\hline Kneeling & - & - & - \\
\hline walking & - & - & 1 \\
\hline load effect & & & - \\
\hline$<10 \mathrm{~kg}$ & 1 & 1 & - \\
\hline$<20 \mathrm{~kg}$ & - & - & $\mathbf{2}$ \\
\hline$>20 \mathrm{~kg}$ & - & - & 2 \\
\hline Action Category & $\mathbf{2}$ & $\mathbf{2}$ & \\
\hline
\end{tabular}

Table 4

Interpretation of results of OWAS

\begin{tabular}{cll}
\hline Score & \multicolumn{1}{c}{ Action } & \multicolumn{1}{c}{ Tools } \\
\hline 1 & No corrective measures & Machine \\
\hline 2 & Corrective measure in near future & $\begin{array}{l}\text { Hand tool } \\
\text { fork }\end{array}$ \\
\hline 3 & $\begin{array}{l}\text { Corrective measures as soon as possi- } \\
\text { ble }\end{array}$ & - \\
\hline 4 & Corrective measures immediately & - \\
\hline
\end{tabular}

\subsection{Rating of perceived exertion/discomfort}

The results of the study also revealed that workers had some sort of exertion and discomfort after pricking task. Though pricking is a sedentary task but as it is done manually and is highly repetitive thereby causes fatigue in upper limbs. However the feeling of pain and discomfort was very low with machine as compared to fork and hand tool.

Table 5

Responses on musculoskeletal problems and perceived exertion experienced by respondents

\begin{tabular}{lll}
\hline $\begin{array}{l}\text { Pricking me- } \\
\text { thod }\end{array}$ & Musculoskeletal problem & $\begin{array}{l}\text { Rating of } \\
\text { perceived } \\
\text { exertion }\end{array}$ \\
\hline fork & $\begin{array}{l}\text { Moderate to light pain in neck } \\
\text { backbone(cervical, lumbar), } \\
\text { right shoulder, right hand, } \\
\text { right wrist, and figures of both } \\
\text { hands }\end{array}$ & Light \\
& -do- & \\
\hline Hand tool & $\begin{array}{l}\text { Low pain in lower arm, wrist } \\
\text { and palm }\end{array}$ & Very light \\
\hline $\begin{array}{l}\text { pricking ma- } \\
\text { chine }\end{array}$ & & \\
\hline
\end{tabular}

\subsection{Sensory of preserve}

Findings revealed that preserve prepared from machine pricked aonla were having highest acceptability among consumers followed by preserve prepared from fork pricked aonla and then hand tool pricked aonla.

Table 6

Sensory of preserve prepared from 3 methods of pricking

\begin{tabular}{lllll}
\hline Methods & Color & Flavor & texture & $\begin{array}{l}\text { Overall accep- } \\
\text { tability }\end{array}$ \\
\hline Fork & 8 & 7 & 8 & 7.66 \\
\hline Hand tool & 7 & 7 & 6 & 6.66 \\
\hline machine & 8 & 8 & 8 & 8 \\
\hline
\end{tabular}

When different pricking tasks were subjectively perceived, using Ratings of perceived exertion, it was find out that they were having different levels of discomfort and exertion. Machine pricking was a low exerting activity as compared to the existing methods. Different tasks when objectively rated, using EAT outcome measures, were having different risks of developing WMSDs. With fork and hand tool the adopted postures were not acceptable in terms of both RULA and OWAS, while with machine RULA scores were not acceptable, however, OWAS scores did not restrict the use of machine. It indicates that machine also needs some modification in terms of RULA acceptable postures. The workers using fork and hand tool were more exposed to develop musculoskeletal problems than workers using machine. It was also found out that rank order of tasks using EATs outcome measures the same as the rank using RPE/RPD scales i.e. fork and hand tool were involving more postural stress and exertion than machine. The reason for awkward posture was lack of proper sitting and working arrangements for the workers. It was suggested that proper sitting arrangements, proper machinery and proper rest periods for workers can solve the problem. There were some posture related problems in which upper arm were under high risk, so proper rest periods were recommended to avoid any MSD in future. Proper sitting and standing workstations have been designed using rack system so that worker can adjust the height of work surface according to their suitability to avoid the problems related to unnatural bending of body parts. However, more work needs to be done to modify the involvement of upper extremities in pricking task. Also, all the workers were made aware about the correct posture while working. 


\section{Conclusion}

The study revealed that musculoskeletal disorders have become a severe problem in small and medium scale enterprises. Awkward posture in the workplaces should be avoided and these industries should be encouraged to follow ergonomic practices and installation of proper machines which will undoubtedly decrease the risk of musculoskeletal problems and therefore workload can be decreased and efficiency can be increased.

\section{Reference}

[1] Annual Report of AICRP on PHT, 2008. CCS HAU
[2] Atamney L. and Corlett E. 1993. RULA: A survey method for the investigation of work related upper limb disorder. Applied Ergonomics, 24(2): 91-99.

[3] Srilakshmi B. 2003. Food Science. New age international publisher. New Delhi

[4] Handbook of Horticulture, 2009. Indian Council of Agricultural Research, New Delhi (India).

[5] Kharu, O;Kansi P;Kuorinka.1977. Correcting working posture in industry: a practical method for analysis. Ergonomics, 8(4), 199-201.

[6] Varghase M.A;Saha P.N;Atreya N. 1994. A rapid appraisal of occupational work load from a modified scale of perceived exertion. Ergonomics, 37(3), 485-491. 